\title{
The impact of site characteristics on the development of wind turbines, as sources of recoverable energy
}

\author{
Dana Madalina Pohrib ${ }^{1, a}$, Anghel Stanciu ${ }^{2, b}$ and Irina Lungu ${ }^{3, c}$ \\ 1,2,3 "Gheorghe Asachi" Technical University of lasi, Romania \\ amadalina.pohrib@yahoo.com banghel.stanciu@yahoo.com cilungu@ce.tuiasi.ro
}

Keywords: wind turbines, foundations, impact, stability, soil stratification

\begin{abstract}
For the design of wind turbines it is necessary to consider several conditions such as: wind, turbulence, temperature variations, geology and characteristics of foundation soils on site, earthquake and neighborhood restrictions. The selection of the types and dimensions of the wind turbines foundations are dependent on the geotechnical conditions, the maximum power of turbines and the type of tower. This paper presents various tower structures correlated with the corresponding types of foundations currently used for wind turbines. For this research, the authors performed a variety of analyses and studies involving different characteristics of the locations for the wind turbines. The research shows the solutions obtained for the pile foundations and their impact upon the environment. The paper points out the influence of the pile length on the slope stability as resulted for the soil stratification from the investigated locations.
\end{abstract}

\section{Introduction}

The location of the wind farms subject to the present study is North-Eastern Romania, within the geological unit Moldavian Plateau (Fig. 1)

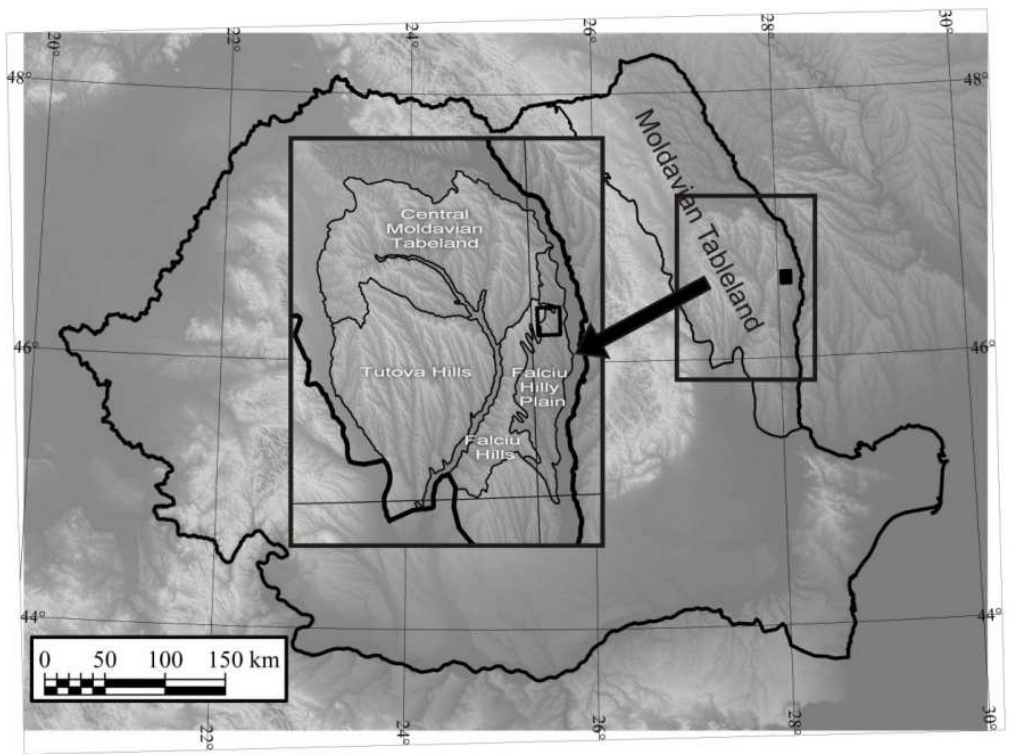

Fig. 1 Location of the wind farms [1]

A representative site has been analysed both from a geotechnical point of view, in order to establish the conditions for the foundation of wind towers, and from the point of view of wind power, that is, the exterior specific actions exerted on the towers.

The load-bearing structure of a high power wind turbine can generally be divided into six substructures, namely: the rotor blades, the generator, the nacelle with rotor, the screwed joints, the tower, and the foundation, Fig. 2. The dimensions of all load-bearing components listed above are established based on the wind turbine capacity. 


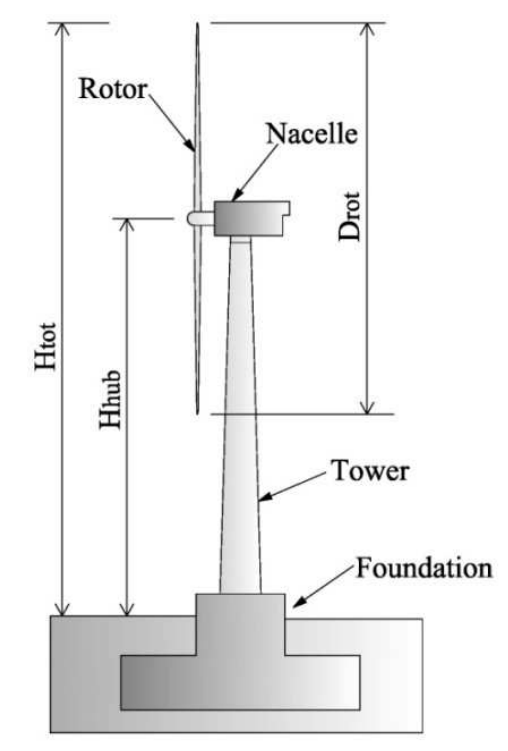

Fig. 2: Development of a wind turbine

\section{Wind power and actions specific to wind turbines}

The kinetic power of the wind, subsequently used in dimensioning the towers, is computed by means of the following relation (1) :

$$
P_{k i n}=\frac{1}{2} \rho A v^{3}
$$

where, $P_{\text {kin }}(\mathrm{W})$ is the kinetic energy, $\rho\left(\mathrm{kg} / \mathrm{m}^{3}\right)$ is the density of the air, $A\left(\mathrm{~m}^{2}\right)$ is the area of the cross section, plane, perpendicular to the direction of the air flow and $v(\mathrm{~m} / \mathrm{s})$ is the velocity of the air, wind speed, passing the cross section.

The most important design parameters for a wind turbine are the wind speed and the turbulence specific to the climatic area where the work is located. The loads transmitted to the structure while the turbine produces energy are induced by the structure and the diameter of the rotor, the blades rotation speed and, respectively, the degree of deceleration resulting from the turbine operation [2]. Throughout their functioning, the design loads are defined based on the 8 operation modes of a turbine: 1.Start-up, 2. Normal operation, 3. Normal shutdown, 4. Emergency shutdown, 5. Standstill (shutdown or tick over), 6. Occurrence of malfunction, 7. Transport, assemblage, maintenance, and service, 8. Seismic event;

\section{The structure of wind turbine towers}

Wind turbine towers are structures with special functional demands, driven by external forces predominantly determined by the climatic conditions of their location and are made of high performance construction materials.
a. Steel towers:
i. Tubular towers
ii. Lattice towers

b. Reinforced concrete towers - with precast tubular structure

c. Hybrid steel and concrete towers - with tubular structure.

a. i. Tubular towers - The steel tubular structure is relatively light and, due to its circular section, presents the same rigidity on every direction; the advantages of this structure include: high torsion rigidity, structure on sections that are relatively easy to install and transport, low maintenance costs, easy access to the nacelle. The main disadvantage of this structure consists in the difficulty to provide a good joint between the tower and the foundation. 
a. ii. Lattice towers The tower structures are made of lattice, dimensioned based on spatial calculation so as to obtain the required resistance and structural rigidity with a minimal quantity of material. Compared to the steel tubular towers, lattice towers use less material, but cannot reach the height of tubular towers, which is why they cannot be used for building high power wind turbines. In this way steel is used in the most efficient manner and the tower weight is smaller than in other towers of similar height. With all the advantages in terms of reduced steel consumption, this lattice structure has the disadvantage of difficult maintenance.

b.Reinforced concrete towers

Two types of reinforcement are used in building such towers: elastic reinforcement made of independent bars (which compose the basic reinforcement) and post-tensioned reinforcement. Passive reinforcement with independent bars creates the bearing capacity during the execution and the elevation of the tower. Taking the loads during the operation of the tower and the assembling of the prefab sections requires the use of an active post-tensioned reinforcement. The advantages of reinforced concrete towers are the following: high rigidity equal on all directions, solidity, and easy maintenance without requiring special plastering. The main disadvantage consists in the difficult transport and installation on site due to the high weight of the sections.

c.Hybrid towers made of concrete and tubular steel

The hybrid towers made of concrete and steel are composed of sections: the lower part is made of reinforced concrete, while the upper part is made of a steel tubular segment. The main advantage presented by this type of tower consists in the possibility to execute its lower part in monolithic reinforced concrete, which allows for creating a better joint between the tower and its foundation.

\section{Principal types of foundations}

The type and dimensions of the foundations used for wind turbines are determined by the geotechnical conditions of the location, the maximum capacity of the turbine [3], and the tower type. When the setting ground has a sufficient bearing capacity to overtake the loads transmitted by the wind turbine, the direct-raft foundation is chosen. The raft dimensions are established for the bearing capacity of the foundation ground, the soil volume laid on the foundation, and the loads originating from the tower structural calculation (Fig.3). It should be mentioned that in the case of wind turbines the seismic action is cumulated with the wind action.

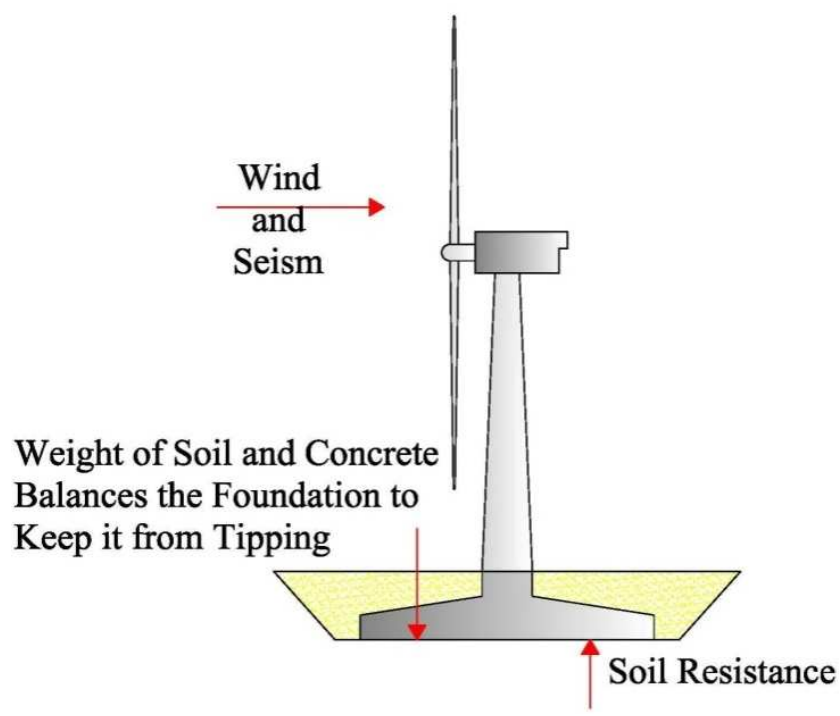

Figure 3: Surface foundation

Where the bearing capacity of the ground is not sufficiently high to ensure safety, piled or bracing foundations are necessary (Fig. 4). The function of the compressed piles is to transfer the loads from the base of the tower to the crossed soil layers, by friction on the side surface, and to the layer on top of the piles, the bedrock in the location. Foundation resistance to tilting results from the settling-lifting compensation, based on the values of piles separation and downward strength. 


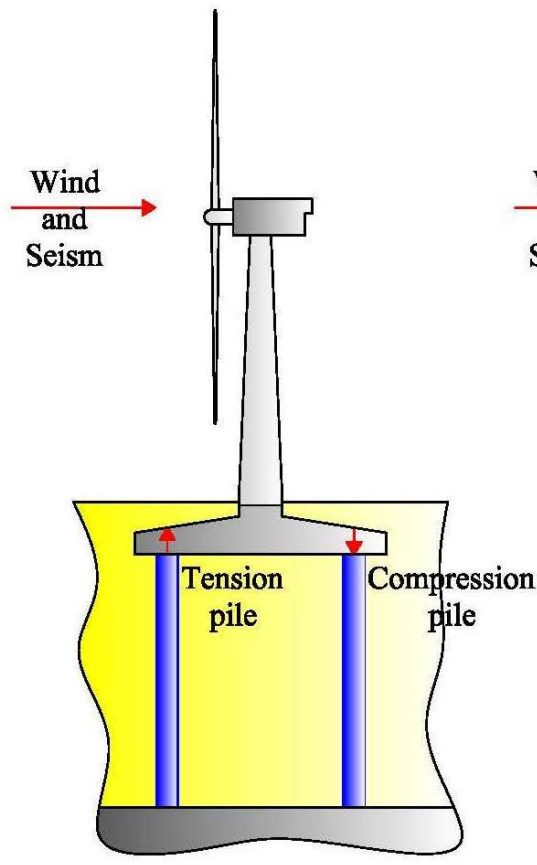

a) Pile Group

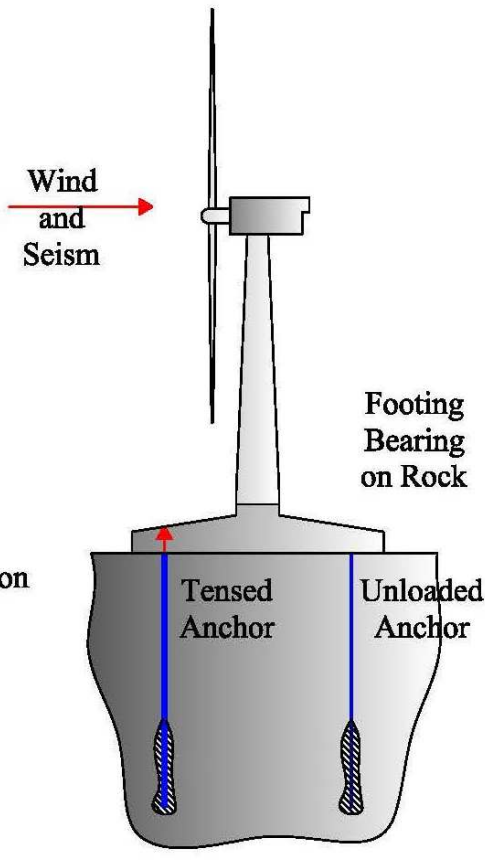

b) Anchored Footing

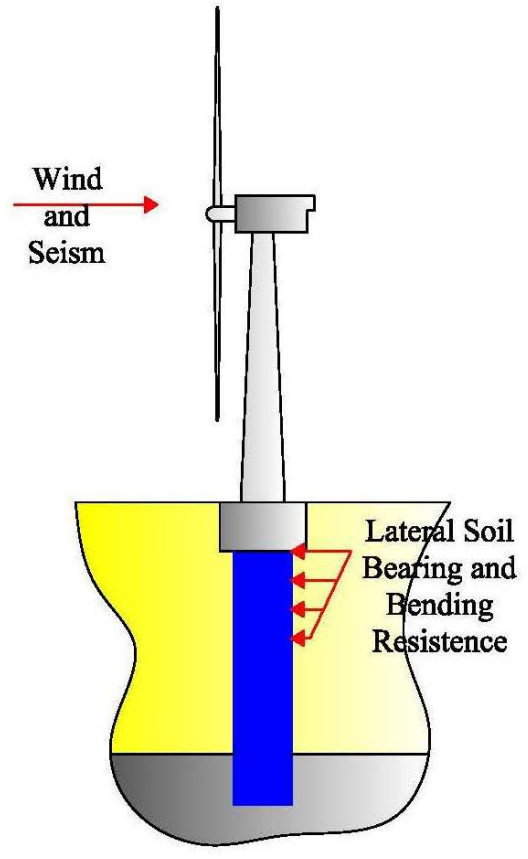

c) Single Pier

Fig. 4 -Various deep foundations, a) spread footing supported by piles, b) spread footing anchored to the bedrock, c) footing supported by a single large diameter pile

The structure of the tower determines the design and the composition of its foundation, as well as of the tower-foundation joint .

\section{Characterization of the wind turbines location}

\section{4. a. Geological characterization}

From a morphostructural point of view, the region where the wind turbines are installed belongs to the southern part of the Moldavian Platform [9]. The depositional architecture is characterized by the alternation of the sedimentary sand-silt-clay bodies, with reduced brownstone and cinerite interlayers attributed to the Chersonian-Meotian age. The depositional succession falls within a TST (transgressive system tract) sequence, laid over the Moldo-Wallachian paleorelief II, formed on the superior Bessarabian repositories [4].

From a geomorphological point of view, the spreading area analyzed here presents the features of the two great physical-geographical units through the contact of which it was shaped, that is, on the one side, the northern limit of Fălciu Hills, a subunit of Barlad Plateau and, on the other side, the highest area of Falciu hilly plane [5].

The characteristic types of relief are a sculptural one, with a hilly fragmentation in the western, north-western and northern region, an area belonging to Falciu Hills, and a hilly one, in the east, south-east and south, typical for a hilly plane. Locally, due to the monoclinal general structure on the NNW-SSE direction of the entire Moldavian Plateau, the hills also acquire an asymmetrical aspect, with a cuesta head type of slope oriented westwards, shorter and more abrupt; the other slope is of the reverse type with an eastwards orientation, prolonged and with a more reduced general descent [6].

\section{4. b. Geotechnical characterization.}

For the comparative analysis, we modelled 2 types of stratigraphic profiles: one profile of the foundation ground is made of a package of cohesive soils, while the other profile where the foundation ground is made of a non-cohesive soil, but which, due to the local geological conditions, presents cementation cohesion. The two situations illustrated are characteristic for an extended 
location in the Falciu area for a wind farm composed of 150 turbines. The geotechnical characteristics of the foundation ground for the two profiles as resulted after drilling, laboratory analyses, and in situ trials with the dynamic cone penetrometer (DCP) [7], [8], are given in Table 1.

Table 1: Characteristics of the two types of stratigraphic profiles analyzed

\begin{tabular}{|c|l|c|c|c|}
\hline \multicolumn{5}{|c|}{ Soil profile 1 - Cohesive soil } \\
\hline $\begin{array}{c}\text { Thickness } \\
{[\mathrm{m}]}\end{array}$ & \multicolumn{1}{|c|}{ Layer name } & $\begin{array}{c}\gamma \\
{[\mathrm{kN} / \mathrm{m} 3]}\end{array}$ & $\begin{array}{c}\mathrm{c} \\
{[\mathrm{kPa}]}\end{array}$ & $\begin{array}{c}\varphi \\
{\left[{ }^{\circ}\right]}\end{array}$ \\
\hline 12 & Silty clay & 18 & 20 & 1 \\
\hline 13.5 & Clay & 19.5 & 30 & 1 \\
\hline 10 & Loamy clay & 20.3 & 120 & 1 \\
\hline \multicolumn{4}{|l|}{ Soil profile 2 - Non-cohesive soil } \\
\hline 12 & Silty sand & 18.1 & 21 & 19 \\
\hline 33.5 & $\begin{array}{l}\text { Consolidated Silty } \\
\text { sand }\end{array}$ & 21.23 & 35 & 25 \\
\hline
\end{tabular}

\section{Analysis of the setting system}

In order to choose the foundation system corresponding to a wind turbine with a concrete tower, we analyzed first the use of a surface raft foundation and, second, the use of a pile foundation. Considering the physical-mechanical characteristics of the silty clay on the ground surface and the size of the loads transmitted by the tower, we concluded that the use of surface foundations is not possible. Plastic areas are developing in the setting ground under the raft (Fig. 5) which precede its exceeded load-bearing capacity.

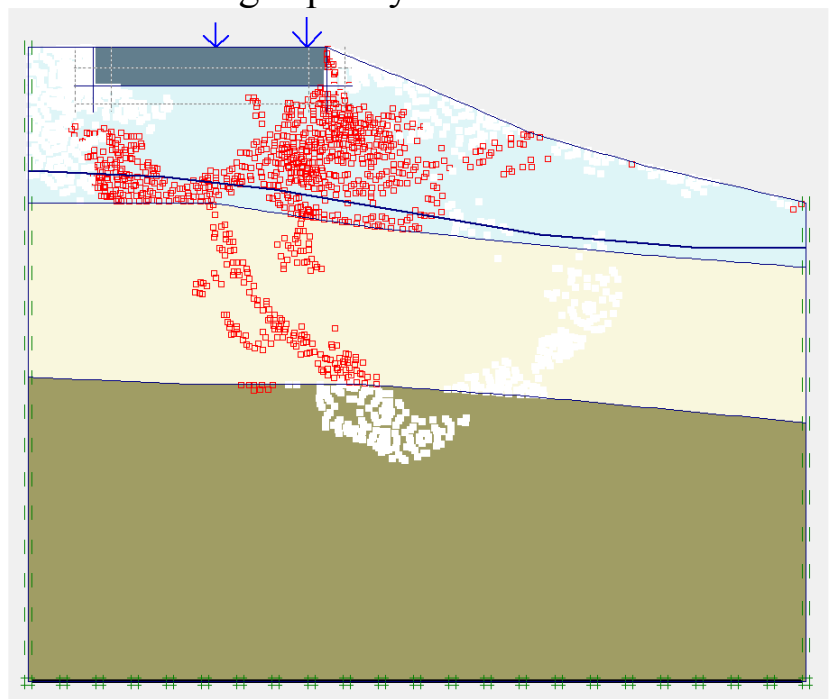

Figure 5: Emergence of plastic areas in case of direct founding

Thus, exceeding the shear strength on extended areas in the foundation ground leads to deformations, settlings and turnings of the foundation, which may even result in the collapse of the wind turbine.

The size of the loads transmitted by the tower to the foundations in correlation with the ground layering led us to consider the use of foundations on high diameter piles, executed on the spot.

In the case of piled foundations for wind turbines, the axial load is accompanied by a side load. The response of the piles to horizontal loads is insignificantly affected by the vertical load.

The minimal length of the piles was determined from the condition that the piles can overtake the loads originating from the tower and safely transmit them to the foundation ground and also from the condition, imposed by the turbine producers, that the maximum slope of the piled foundation be smaller than $3 \mathrm{~mm} / \mathrm{m}$. 
The analyses carried out with the PLAXIS program determined for the stratigraphic profile with cohesive soils a minimal length of the piles of $24 \mathrm{~m}$ (Fig. 6), and of $19 \mathrm{~m}$ (Fig. 7) for the profile with non-cohesive soils. The minimal length of the piles is justified by the physical-mechanical characteristics of the stratification on the two locations, which imposed the use of floating piles, as the layer with very high rigidity and reduced compressibility is found at a high depth, respectively over $50.0 \mathrm{~m}$, in the non-cohesive soils profile, and loamy clay intercepted on the cohesive soils profile present a relative compaction at $200 \mathrm{kPa}$ higher than $2.5 \mathrm{~cm} / \mathrm{m}$.

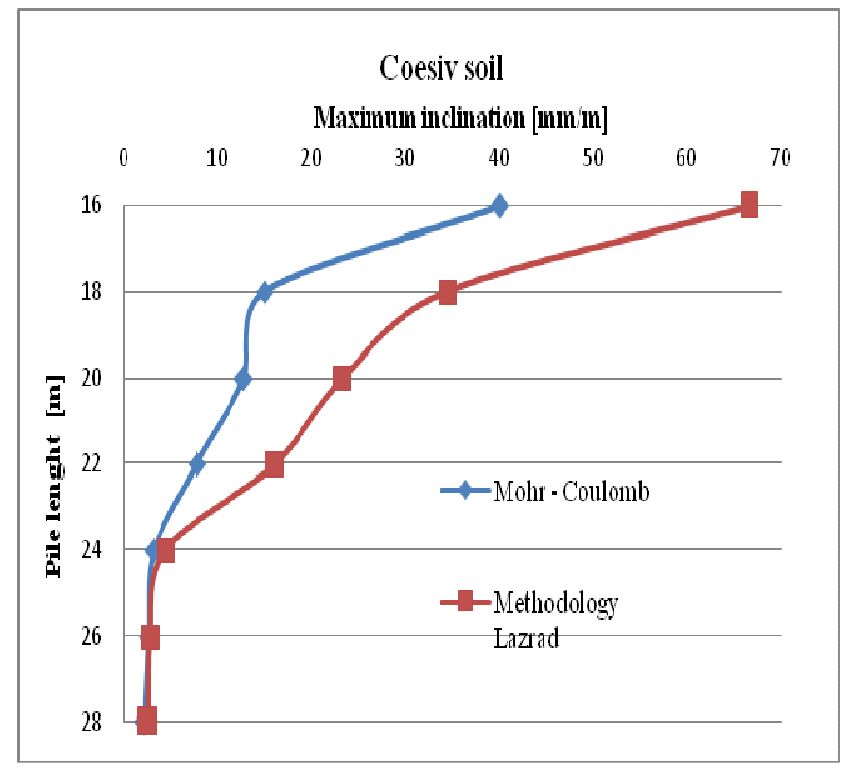

Fig. 6: Variation of the foundation slope based on the length of the piles in the case of the cohesive soils stratigraphic profile

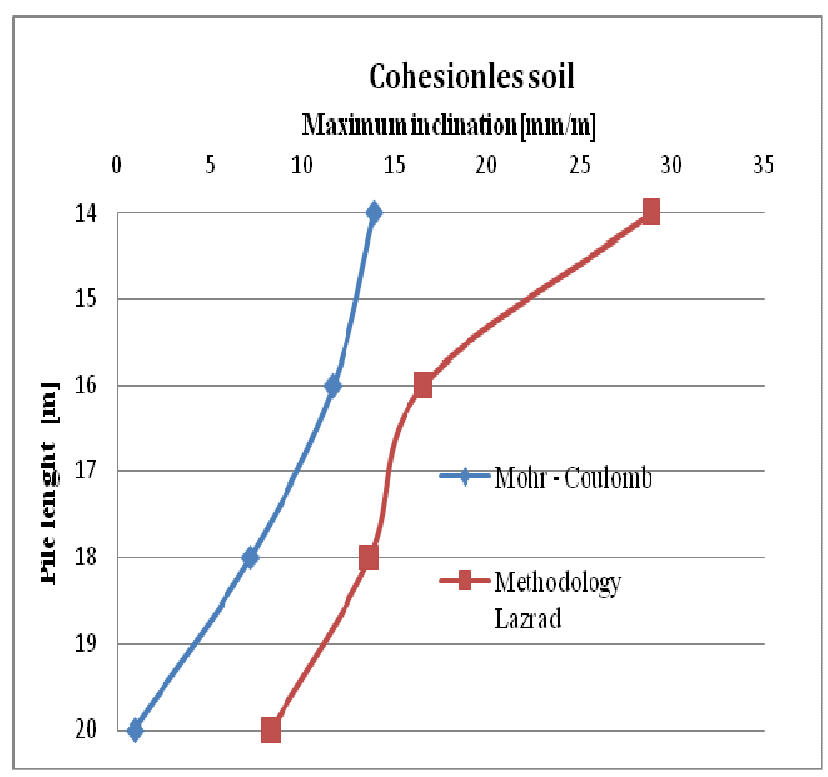

Fig. 7: Variation of the foundation slope based on the length of the piles in the case of the noncohesive soils stratigraphic profile

Table 2: Deformations and efforts alongside the pile

\begin{tabular}{|c|c|c|c|c|c|}
\hline $\mathbf{z}$ & $\mathbf{z} / \mathbf{d}$ & $\mathbf{y}(\mathbf{z})$ & $\boldsymbol{\theta}(\mathbf{z})$ & $\mathbf{M}(\mathbf{z})$ & $\mathbf{T}(\mathbf{z})$ \\
\hline$[\mathrm{m}]$ & {$[-]$} & {$[\mathrm{m}]$} & {$\left[{ }^{\circ}\right]$} & {$[\mathrm{kNm}]$} & {$[\mathrm{kN}]$} \\
\hline 1 & 0.07 & -0.009 & 0.00461 & 871.44 & 73.73 \\
\hline 2 & 0.14 & -0.005 & 0.00333 & 787.05 & 107.64 \\
\hline 3 & 0.21 & -0.002 & 0.00222 & 669.31 & 134.98 \\
\hline 4 & 0.28 & 0.000 & 0.00133 & 529.13 & 145.55 \\
\hline 5 & 0.35 & 0.001 & 0.00064 & 384.43 & 140.10 \\
\hline 6 & 0.42 & 0.001 & 0.00019 & 279.36 & 118.82 \\
\hline 7 & 0.49 & 0.001 & -0.00008 & 250.06 & 96.48 \\
\hline 8 & 0.56 & 0.001 & -0.00020 & 115.19 & 65.81 \\
\hline 9 & 0.63 & 0.001 & -0.00025 & 3.42 & 37.71 \\
\hline 10 & 0.70 & 0.001 & -0.00024 & -17.05 & 13.50 \\
\hline 11 & 0.77 & 0.000 & -0.00021 & -34.34 & -3.56 \\
\hline 12 & 0.84 & 0.000 & -0.00018 & -19.01 & -10.83 \\
\hline 13 & 0.91 & 0.000 & -0.00016 & -8.49 & -10.09 \\
\hline 14 & 0.98 & 0.000 & -0.00015 & -1.89 & -2.55 \\
\hline 15 & 1.05 & 0.000 & -0.00015 & 0.00 & 0.00 \\
\hline & & & & & \\
\hline
\end{tabular}

The deformations and the efforts alongside the most stressed pile, according to the beam theory on Winkler foundation [9], [10], are given in Table 2, and the variation diagrams are given in Fig. 8. 


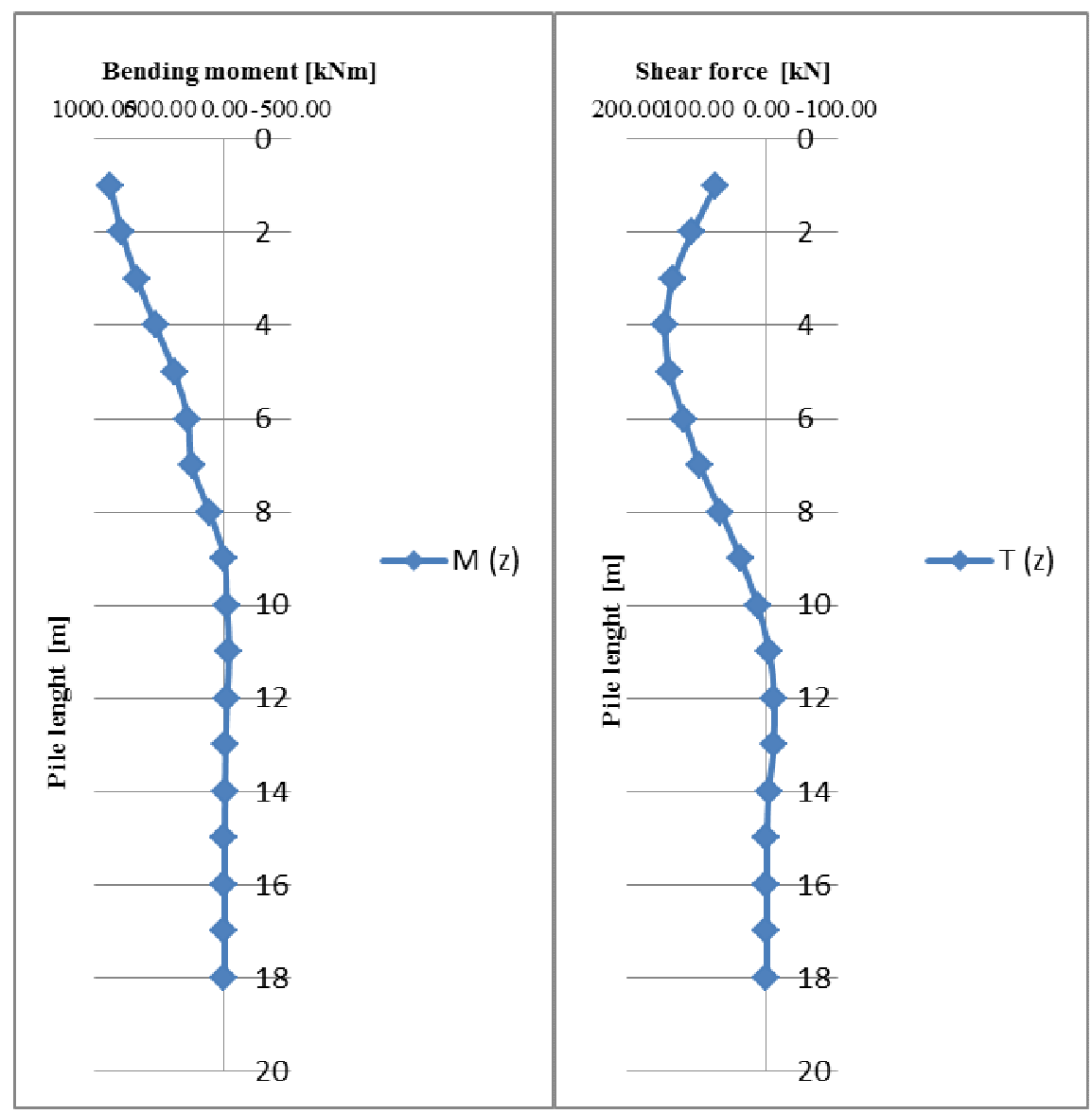

Figure 8: Efforts in the pile

\section{The influence of pile length on slope stability}

The analysis of the slope stability, based on characteristic calculation profiles and in the presence of the piled foundations of a wind turbine, aimed to assess the influence of pile length on preventing a generator failure/ landslide. The behaviour of the grounds used from the sites is defined by means of the Mohr-Coulomb model, and the stability analysis aims iteratively, with the help of the PLAXIS 2D program, to use the Blocks method - Lazard methodology to calculate the safety factor [11].

Thus, maintaining the same geometry of the slope along the selected calculation profile, the stability analysis relies, for the two distributions of the site layers, on pile lengths within the range 14- $28 \mathrm{~m}$. From the landslides prevention condition there results a sufficient length of the piles, amounting to $20 \mathrm{~m}$. This length is smaller than the one required for avoiding a GEO failure $(24 \mathrm{~m})$ of the foundation in the stratigraphic distribution of cohesive soils; consequently, the $24 \mathrm{~m}$ length is enough to avoid landslide in the area. Contrary to this situation, for non-cohesive soils, the $20 \mathrm{~m}$ length necessary to prevent landslide is greater than the $19 \mathrm{~m}$ length in the bearing capacity condition (GEO) of the foundation, so the final length is $20 \mathrm{~m}$. In the case of non-cohesive soils, it was noticed that the failure/ landslide surface occurs downraft in the slope, while in the case of cohesive soils, the failure / landslide surface occurs under the raft.

\section{Conclusions}

Wind turbines are placed mostly on slopes due to the favourable wind conditions that drive the efficient functioning of these constructions.

Our paper presents the synthetic results of a study on wind turbines tower foundations using piled foundations on a site in Moldavian Platform, based on two representative stratigraphic profiles which consist of a sequence of cohesive soils (case 1), and a sequence of non-cohesive soils (case 2). 
The minimum pile length established in the load-bearing capacity condition of the foundation soil proved to be satisfying, in the cohesive soil stratigraphic profile, for preventing landslide on the site. For the case of non-cohesive lands, pile length is dictated by the need to prevent landslide at the expense of the conditions imposed by avoiding the bearing capacity limit state.

The stress in the piles generated by the anticipated potential pushing on the breaking/ slide surface are reduced (31\% from the capable moment and $10 \%$ of the capable cutting force) compared to the stress required in the piles as foundation elements.

ACKNOWLEDGMENT: This paper was supported by the project "Development and support of multidisciplinary postdoctoral programmes in major technical areas of national strategy of Research - Development - Innovation" 4D-POSTDOC, contract no. POSDRU/89/1.5/S/52603, project cofunded by the European Social Fund through Sectoral Operational Programme Human Resources Development 2007-2013.

\section{References}

[1] Madalina Dana Pohrib, Anghel Stanciu,Lilian Neacsu "Wind farms, solution for the economization of the terrains in Falciu Hills( Padureni area)", Buletinul I.P.I., Sectia Constructii. Arhitectură, Tomul XLII (LXI). Fasc. 2, pag. 105 - 121, 2011

[2] Elforsk rapport 11:56, Cracks in onshore wind power foundations - Causes and consequences January 2012,

[3] NP 112/2004 - Normativ pentru proiectarea structurilor de fundare directa.

[4] Săndulescu, M., 1984. Geotectonica României. Edit. Tehnică, Bucureşti, 450 pp

[5] Ungureanu Al., 1993. Geografia podişurilor şi câmpiilor României, Edit. Univ. „Al.I.Cuza” Iaşi, 246p

[6] Madalina Dana Pohrib, Doru-Toader Juravle, Lilian Niacsu, Adrian Ursu, Anghel Stanciu, Dorel Platica: Paleogeography of the Chersonian to Meotian in the north of Fălciu Hills (Moldavian Platform) based of sedimentological data, Carpathian Journal of Earth and Environmental Sciences, ISSN Printed 1842-4090, ISSN Online 1844 - 489X , vol.7., No.2, mai 2012, pp.23-36 (14 pagini). Factor de impact pe anul 2010: 1,579. Factor de impact/autor 0.263 . Indice de rapiditate al citarilor (Revista) pe 2011:0,426

[7] SR EN 1997/1 - Proiectarea geotehnică. Partea 1: Reguli generale

[8] SREN ISO 22476 -2 - Cercetari si incercari geotehnice. Incercari pe teren. Partea 2 : Incercarea de penetrare dinamica.

[9] NP 123 - 2010, Normativ privind proiectarea geotehnică a fundatiilor pe piloti

[10] SR EN 61400/1 - Turbine eoliene. Partea 1: Conditii de proiectare

[11] Stanciu, A.,Lungu, I. Fundatii, Edit. Tehnica, Bucuresti,2006 